\title{
DISPARITIES IN LITERACY OF UDAIPUR DISTRICT, RAJASTHAN
}

\author{
Shivani Swarnkar ${ }^{1}$ and Sandhya Pathania ${ }^{2}$ \\ ${ }^{1}$ Assistant Professor, ${ }^{2}$ Associate Professor, \\ Department of Geography, Govt. M.G. College Udaipur (Rajasthan) India \\ Email:pswarn7@gmail.com
}

\begin{abstract}
An individual is a social being and needs economic welfare. A healthy society in turn, needs healthy and literate individuals. In order to make literacy worthwhile, it must be functional. Functional literacy signifies the ability of a person to discharge his economic, social and civic duties in an efficient manner. The word 'Literacy' means an ability to read and write. The level of development becomes higher if the population of the country is educated and firstly literate. Education permits a higher degree of social mobility the ability to achieve a higher social level. This paper is an effort to analyze the position of literacy in 11 tehsils of Udaipur district at social level, gender level with the statistical techniques based on census data of 2011. The purpose of the paper is to find out what are the causes of social and gender disparity in literacy regarding the 11 tehsils of Udaipur district and the attempts that can be inculcated to make the females of the district and the social groups more literate.
\end{abstract}

Key words: Disparities, Education, Literacy, Social and Gender

\section{Introduction}

Education is must for both men and women equally as both together make a healthy and educated society. It is an essential tool for getting bright future as well as plays an important role in the development and progress of the country. Literacy is traditionally understood as the ability to read, write and use arithmetic. The modern term meaning has been expanded to include the ability to use language, members, images, and computers, other basic means to understand, communicate, and gain useful knowledge. UNESCO defines literacy as the ability to identify, understand, interpret, create, and communicate and computer using printed and written materials associated with varying contexts. In the present paper an attempt has been made to find out the disparities of literacy in Udaipur district. Udaipur district has been taken as study area. Schedule Tribe population is more here and literacy is less. Literacy percentage is less in some tehsils. For increasing educational development it is important to find out that which regions have less percentage (percent) of literacy.

\section{Study Area}

Udaipur district is one of the 33 districts of Rajasthan state in Western India. It is one of the seven divisions in Rajasthan. It has its head quarter at Udaipur and has eleven tehsils namely Bhinder, Girwa, Gogunda, Jhadol, Kherwara, Kotra, Lasadiya, Mavli, Rishabhdeo, Salumber, Sarada. It has an area of $11,724 \mathrm{sq}$. $\mathrm{km}$ and has a population of 3,068,420 (2011), density is $260 \mathrm{~km}^{2}$. Udaipur has an urban density of 19.83 percent, literacy 61.82 percent and sex ratio of 958. National Highway 876 passes through it. Udaipur district is bounded by Aravali Range on the North West (across which lie the districts of Sirohi and Pali). It is bounded on the North by Rajsamand district, on the East by Chittorgarh district, on the South East by Banswara district, on the South by Dungarpur district, and on the South West by state of Gujarat. It is part of Mewar Region of Rajasthan. Udaipur district has latitudinal extension from $23^{\circ} 46^{\prime} \mathrm{N}$ to $25^{\circ} 5^{\prime} \mathrm{N}$ and longitudinal extension is from $73^{\circ} 9^{\prime} \mathrm{E}$ to $74^{\circ} 35^{\prime} \mathrm{E}$. In 2011 , total population of Udaipur district has been $30,68,000$ comprising of $15,66,000$ males and $15,02,000$ females. Out of the 
total population $1,89,000$ are schedule caste and $15,25,000$ are schedule tribes. Schedule caste contributes 11.55 percent of the state and schedule tribe 16.51 percent.

Udaipur district comprises eight sub divisions - Girwa, Kherwada, Mavli, Vallabhnagar, Kotda, Jhadol, Rishabhdeo and Salumber which are further divided into 11 tehsils, Girwa sub division consists of two tehsils - Girwa and Gogunda, Kherwara also comprises of two tehsils Kherwara and Rishabhdeo. Salumber comprises of three tehsils - Lasadia, Salumber and Sarada and rest have only one tehsil. Udaipur district has a population of 3,068,420 having 90 percent Hindu, 9 percent Muslim and 1 percent others. This gives it a ranking of $118^{\text {th }}$ in India (out of a total of 640). The district has a population density of 242 inhabitants per square kilometer. Its population growth rate over the decade 2001-2011 has been 2366. Udaipur has a sex ratio of 958 females per thousand males and a literacy rate of 62.74 percent. Its population comprises 4.48 percent of the state.

\section{Objectives}

1. To find out gender wise disparity in literacy.

2. To find out social group wise disparity in literacy.

\section{Methodology}

The collection of data of 11 tehsils of Udaipur district is done at district secondary level from various government organizations. Data related to demographic status, literacy is collected from Census - 2011. The representation of data has been done by using cartographic techniques like tables, maps, helped in data representation. Maps are prepared using Arc GIS 10.1. Present paper is an attempt to throw light on the role of literacy in socio economic development of Udaipur district at Tehsil level. Literacy rate in 2011 of Udaipur district has been 51.58 percent, 62.12 percent in males and 40.56 percent in females.

\section{Literacy an Overview}

Regarding literacy the world include people of age group above 15 who can read and write. 86.1 percent of total population is literate out of which 89.9 percent of male are literate and 82.2 percent of females are literate (2015). More than three quarters of the worlds (758 millions) illiterate adults are found in South Asia and East Saharan Africa of all the illiterate adults in the world, almost two third are women (2014). Literacy in India is a key for socio economic progress and the Indian Literacy rate has grown to 74 percent as per census 2011 from 12 percent at the end of British rule in 1947. The level of literacy is below the world average literacy rate of 84 percent and of all the nations, India currently has the largest illiterate population. There is a wide gender disparity in the literacy rate in India effective literacy rates (age 7 and above) in 2011 has been 82.14 percent for men and 65.46 percent for women.

Rajasthan's literacy rate of Rajasthan has witnessed aloft tendency and it has been 66.11 percent as per 2011 census. Literacy rate in males has been 79.19 percent and in females 52.12 percent. Cities of Rajasthan having high literacy rate as per census 2011 are Kota, Jaipur, Jhunjhunu, Sikar, Alwar where literacy rate falls in between 70 to 77 percent and cities having lowest literacy rate are Jalore, Sirohi, Pratapgarh, Banswara and Barmer where literacy rate is from 54 to 57 percent. In present paper the calculation of literacy is done from age 7 onwards of 11 tehsils of Udaipur district. Table no. 1. and Map No. 1. Clearly shows disparities in Average literacy rate among different block of Udaipur District. Total population literacy is divided into three categories below 40 in which two tehsils of Jhadol and Kotra come, than from 40-70 in this category 8 tehsils are coming namely; Kherwara, Rishabhdeo, Vallabhnagar, Sarada, Mavli, Salumber, Lasadiya and Gogunda, Girwa has literacy percentage above 70 . 
Table 01: Literacy (Percent) Rate in Udaipur District, 2011

\begin{tabular}{|c|c|c|c|c|c|c|c|c|c|c|c|c|}
\hline Tehsil & \multicolumn{3}{|c|}{ Literacy } & \multicolumn{3}{|c|}{ Schedule Cast } & \multicolumn{3}{|c|}{ Schedule Tribes } & \multicolumn{3}{|c|}{ General } \\
\hline & Total & Male & Female & Total & Male & Female & Total & Male & Female & Total & Male & Female \\
\hline Girwa & 77.18 & 86.54 & 7.30 & 8.16 & 88.09 & 67.52 & 53.06 & 68.60 & 37.01 & 86.49 & 93.27 & 79.28 \\
\hline Go & .14 & 6.60 & 5.12 & 9.52 & 74.08 & 44.29 & 35.80 & 50.02 & 1.13 & 65.79 & 2.64 & 48.26 \\
\hline Jhadol & 52.42 & 66.43 & 38.14 & 62.86 & 75.76 & 49.17 & 48.04 & 61.98 & 34.02 & 65.29 & 79.29 & 50.46 \\
\hline Kherwara & 65.89 & 81.11 & 50.27 & 69.21 & 82.85 & 54.97 & 63.59 & 79.34 & 47.46 & 72.36 & 86.22 & 58.06 \\
\hline Kotra & 26.58 & 36.43 & 16.49 & 41.72 & 57.08 & 25.08 & 24.88 & 34.55 & 15.03 & 67.08 & 78.03 & 54.57 \\
\hline Lasadiya & 9 & 48.86 & 21.72 & 4.79 & 3.53 & 40.72 & 31.79 & 44.96 & 18.26 & 2.18 & 76.79 & 46.74 \\
\hline Mavli & 61.96 & 76.83 & 46.75 & 2.94 & 3.24 & 47.16 & 40.79 & 56.83 & 24.42 & 67.65 & 82.14 & 52.86 \\
\hline Rishabhdeo & 63.62 & 78.76 & 47.97 & 66.13 & 78.26 & 52.76 & 60.67 & 76.62 & 44.34 & 80.39 & 91.16 & 68.85 \\
\hline Salumbar & 57.12 & 71.92 & 42.08 & 67.34 & 81.21 & 52.79 & 44.72 & 59.76 & 29.57 & 70.57 & 85.09 & 55.72 \\
\hline Sarada & 60.21 & 75.24 & 44.65 & 62.06 & 75.32 & 48.00 & 55.22 & 70.17 & 39.80 & 69.02 & 84.41 & 53.05 \\
\hline Vallabhnagar & 62.68 & 77.87 & 46.95 & 63.15 & 79.10 & 46.67 & 45.55 & 61.45 & 29.42 & 66.84 & 81.72 & 51.37 \\
\hline
\end{tabular}

Source: District Census Abstract, GOI, 2011

\section{Gender Disparity in Literacy}

Table 1 clearly shows gender wise disparities in literacy rate among different block of Udaipur District. Amongst the eleven tehsils of Udaipur district regarding male literacy below 60 percent is in Lasadiya. Kotra, Jhadol, Gogunda, Salumber, Sarada, Mavli, Vallabhnagar, Rishabhdeo fall in middle category of literacy which has been taken from 60 to 80, two tehsils namely Kherwara and Girwa have literacy more than 80 percent. Lasadiya, Kotra tehsils of Udaipur district have literacy percentage below 30. Seven tehsils namely Gogunda, Jhadol, Salumber, Sarada, Mavli, Vallabhnagar, Rishabhdeo have literacy rate between 30-50 percent, above 50 percent literacy rate in females are of Kherwara and Girwa tehsil. While ranking after computing, Sarada tehsil ranks $5^{\text {th }}$ in total literacy but sixth in male and female literacy, percentage, on the other hand Mavli ranks fifth in total population literacy rate but ranks fifth in male and female literacy percentage. In total literacy population Lasadiya rank $8^{\text {th }}$, Gogunda $9^{\text {th }}$ and Jhadol at $10^{\text {th }}$ place whereas in male literacy percentage Gogunda rank $8^{\text {th }}$, Jhadol at $9^{\text {th }}$ position and Lasadiya at $10^{\text {th }}$ place. The change again came in $8^{\text {th }}, 9^{\text {th }}$ and $10^{\text {th }}$ position of Jhadol, Gogunda, Lasadiya respectively in female literacy percentage.

\section{Disparities in Social Group}

A group becomes social when interaction interplays among its participants. Over an appreciable period of time and who act in accordance with common function or purpose. In Udaipur districts, social groups mainly include schedule caste, schedule tribes and general caste. Table no. 1 and Map No. 2. shows social group wise disparities in literacy rate among different block of Udaipur District. According to 2011 census, Kotra tehsil has lowest literacy rate i.e. below 50 in relation to total schedule caste population residing in Kotra tehsil, Girwa has highest schedule caste literacy rate, in the remaining tehsils of Lasadiya, Gogunda, Sarada, Jhadol, Mavli, Vallabhnagar, Rishabhdeo, Salumber and Kherwara literacy rate lies between 50 to 70 percent. In relation to schedule tribes literacy rate, Kotra tehsil has literacy below 30 percent amongst the three categories made Lasadiya, Gogunda, Mavli, Salumber, Vallabhnagar, Jhadol have come in the category which literacy rate in between to 30 to 50 percent. In above 50 percent literacy rate category comes four tehsils of Udaipur district namely Girwa, Sarada, Rishabhdeo and Kherwara. Besides schedule caste and schedule tribes, the literacy rate in general caste has also been categorized into three types, below 65 in which Lasadiya tehsil has come between 65 to 80 percent, in which this category 8 tehsils have come namely Jhadol, Gogunda, Vallabhnagar, Kotra, Mavli, Sarada, Salumber, Kherwara and lastly is above 80 percent category having Rishabhdeo and Girwa tehsil in it. 


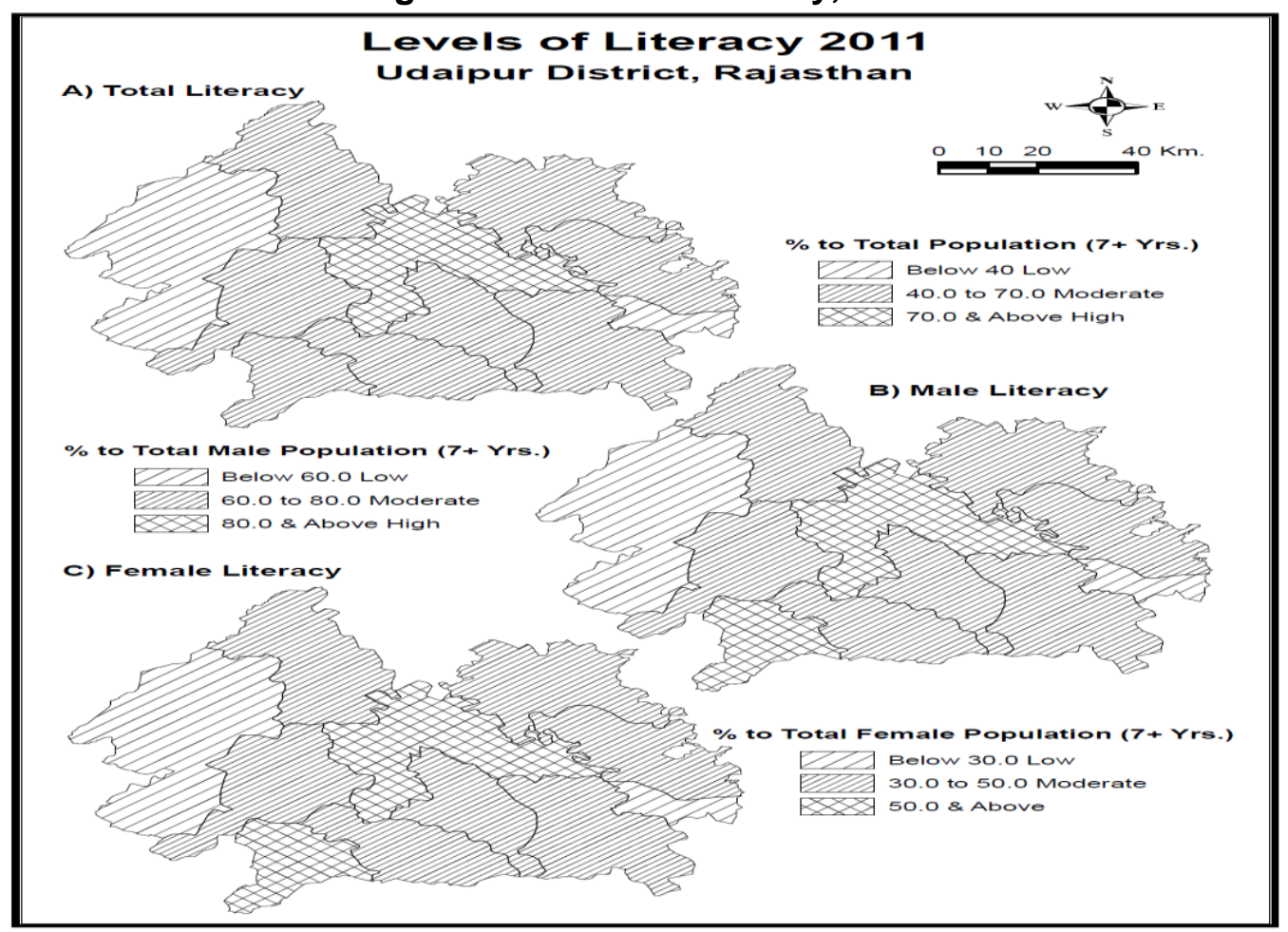

Figure 02: Total Literacy by Social Groups, 2011

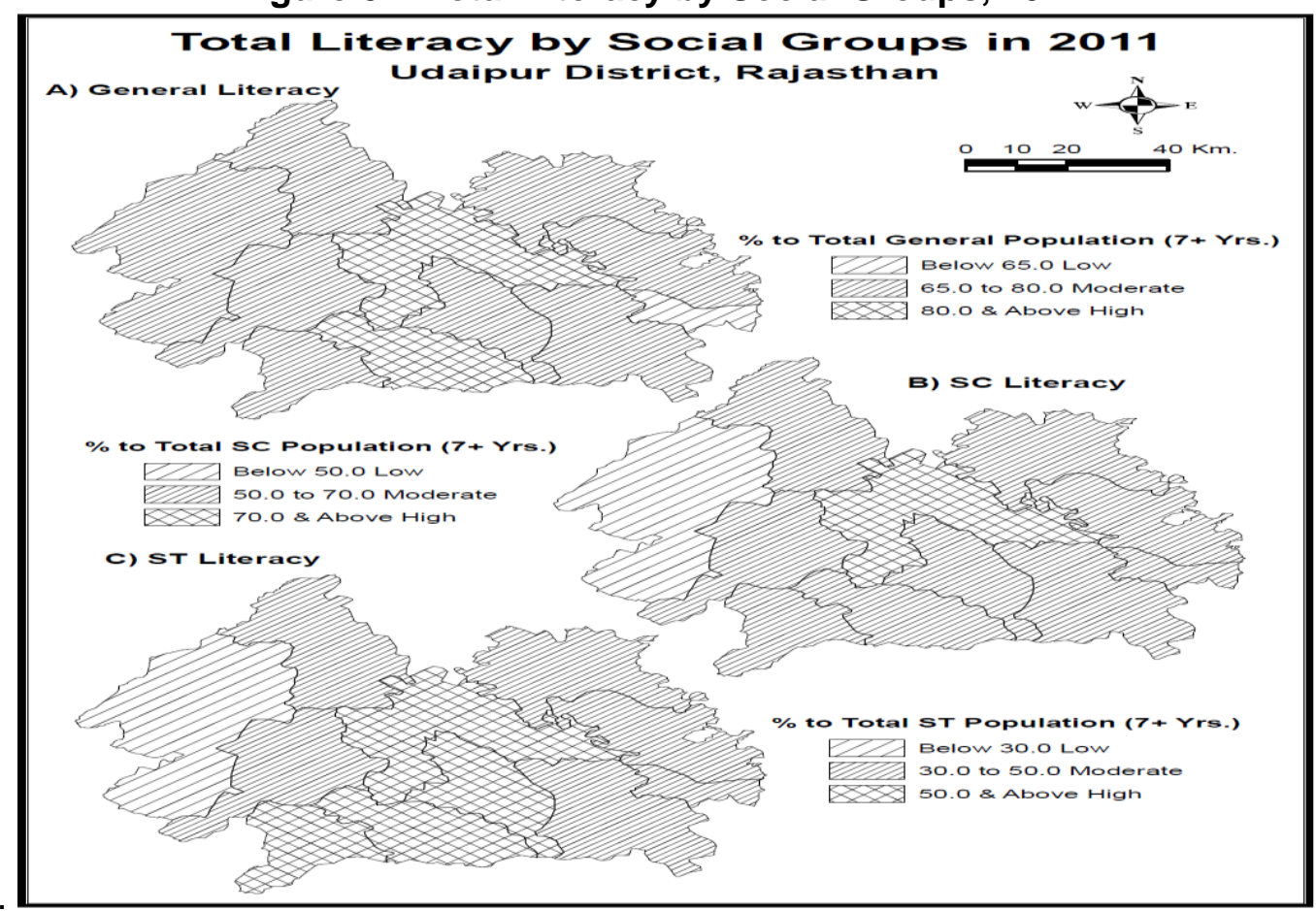

Looking at the literacy rate in the three categories of social group of Udaipur district, tehsil wise literacy rate is showing a different pattern. Kotra tehsil has minimum schedule caste and schedule tribe's literacy rate but ranks at $7^{\text {th }}$ place in general literacy rate. Girwa tehsils stands at first place in schedule caste literacy rate and general literacy rate at $4^{\text {th }}$ place in schedule tribe's literacy rate. Even in education of literacy rate of these social groups 0-6 age group is not taken. Eastern part of this district is more developed then western part and this development impact. The reasons for less literacy percentage in the tehsils are.

1. Geographical Cause: Eastern part of this district is more developed then western part and its impact seen on literacy. Kotra tehsil is tehsil with more of schedule tribes population 
where till today nuclear families reside far for on mountains. In this situation the people of this district have not developed connectivity and the desired results are not achieved.

2. Social Causes: The social structure in the tribal belt is such that males of the tribes are engaged in agriculture, no. $\mathrm{n}$ agriculture, and labour work. The females of the district are engaged in agriculture, animal husbandry, family and social causes because of which they lose interest in education. Besides this Udaipur district tribal district has various social problems like child marriage, parda pratha, liquor and other addiction.

3. Economic Causes: The district has scarcity of employment sources. For livelihood, population depends on labour and agriculture. Due to insufficient sources of irrigation agriculture is dependent on monsoon and the agriculture fields are very small as a result of which the produce is also not adequate therefore whole family is involved in labour.

4. Lack of Transportation Facilities: Udaipur district lies in Aravali region because of mountainous region the district has lacks in means of transportation which is a very big reason of the isolation of the residents of this district. Being is less contact due to lagging behind in transportation the population of this district has their own culture and is unaware of the urban culture and new technology.

5. Migration: The boundary of the district is joining Gujarat state boundaries at many places which makes the people of this district migrate to Gujarat for employment purpose.

\section{Efforts to be done for increasing Literacy Rate}

Following efforts can be made in the various tehsil of Udaipur district for increasing literacy rate:

1. Organizing various educational camps for females of the district.

2. Each one teaches one system should be adopted in tehsils with geographical dissimilarity. In this system by the teachers and students of the schools efforts can be made to educate the uneducated/illiterate mass of the tehsils lacking in literacy.

3. Responsibility of Educating by B.Ed. Trainees: B.Ed. trainees can educate two uneducated.

4. The motivator propagators of education should be given an aim to meet after which they should be given remuneration which will help in the success of the program.

5. Arrangements for educating at working place within employment guarantying programs: In Udaipur district employment oriented programme are being organized where large number of female labourers are working. To educate them, the motivators of these education centers are given the responsibility, who do the teaching at the work place for an hour.

6. Remuneration on the basis of work: earlier the motivators of the education centers had to educate 10 illiterate monthly. After training only the remuneration was provided.

In nut shell this research paper gives the spatial framework for reducing disparities in literacy.

\section{References}

1. Banerjee, M. (1977). Pattern of sex Ratio in Singhbhum District, Bihar. Geographical Review of India, 39, 30-38.

2. Chandana, R. C. (2002). Geography of Population Concept, Determinants and Patterns. New Delhi: Kalayany Publishers Pvt. Ltd.

3. Dey, J. (2015). Declining Sex Ratio in Sikkim: A spatial Analyis. The NEHU Journal, 13 (2), 63-73. 5. Kour, S. (2013). A geographical Analysis of Literacy and Sex Ratio of Kashmir. The Deccan Geographer, 51 (1\& 2), 75-81.

4. Kayamkhani, I. M.; Chaplot, B. (2014). Comparative Analysis of Literacy Sex Ratio in Rajasthan. Annals of Rajasthan Geographical Association, 31, 78-85.

5. Meena, R. R. (2011). District census Handbook Jalore Village and Town Directory Series 09 Part 12. Jaipur: directorate of Census Operations Rajasthan.

6. Pakhare, B. (2015). Inequality and Correlation between Literacy Rate and Sex Ratio in India: Geographical Analysis. Indian Journal of Regional Science, XLVII (1), 120-124.

7. Swarnkar, S. and Ola, C.D. (2020). Spatial Variation in Literacy of Pratapgarh District, Rajasthan. http://www. Purakala.com/index.php/ ISSN 0971-2143 Vol. 3. 1438-1447. 